\title{
TÖRÖK HÓDOLTSÁG KORABELI SZAKRÁLIS ÉPÍTÉSZET PÉCSETT
}

\section{RELIGIOUS ARCHITECTURE IN PÉCS DURING THE PERIOD OF OTTOMAN HUNGARY}

\author{
Major Róbert, ${ }^{1}$ Kósa Balázs ${ }^{2}$ \\ Pécsi Tudományegyetem, Müszaki és Informatikai Kar, Vizuális Ismeretek Tanszék, Pécs, Magyarország \\ ${ }^{1}$ major.robi1192@gmail.com \\ ${ }^{2}$ kosa.balazs@mik.pte.hu
}

\begin{abstract}
In today's increased pace of life there are some things with incomparable meanings that we are getting too used to. Because of this, architects today play a very big role in the defense of the legacy of our architecture. It is our duty and responsibility to keep defending this legacy, but not stop at just the level of simple preservation. The city of Pécs is filled with architectural remains from different time periods, but most of all buildings from the era of Ottoman Hungary. This architectural heritage were left from one of the bloodiest time periods from the history of our country, and it has become a symbol for the city. In the shadow of the Ottoman Empire, Pécs became an important trading and cultural center, which was a bridge between east and west, north and south. While some of the buildings left from this era were brought public awareness to, a lot of them were forgotten, and only a few people know about what architectural treasures the city holds.

In this paper I would like to highlight some of the forgotten Ottoman heritage, focusing on the religious buildings. As a conclusion to this paper, I would like to present an architectural plan to bring attention to these buildings.
\end{abstract}

Keywords: historic buildings, Pécs, turkish, sacred, tomb of Idrisz baba, mosque.

\section{Összefoglalás}

A mindennapok rohanásában olyan dolgok válnak megszokottá és felejtődnek el, amik egyedülálló jelentőséggel bírnak. Épített örökségünk védelmében az építészeknek kiemelten nagy szerepe van.

Pécs városa bővelkedik a különböző korokból ránk maradt építészeti emlékekben, ezek közül is kiemelkedőek a Török Hódoltságból származó építmények, amik mára a város jelképévé nőttek. A török félhold árnyékában Pécs egy olyan kereskedelmi és kulturális központ lett, ami kapcsolat volt kelet-nyugat, és észak-dél között. Bár néhány ebből a korból származó épületet a köztudat kiemelt, sokra a feledés várt és mára már kevesen tudják, hogy mennyi kincset rejt a város.

Munkánkban ezeket az emlékeket vizsgálom, kiemelten a szakrális építményeket. Eredményeként olyan tervet kívánok bemutatni, ami felhívja ezekre az építményekre a figyelmet

Pécs egyik történelmi nevezetessége a török kórból megmaradt épületek összessége, ezek közt akad olyan, ami máig őrzi hagyományos funkcióját, de van, amit átalakítottak és akadnak romok is. Munkánk során végig vettük a város török emlékeit és kiemelve egyet - Idrisz baba türbéjét - egy tervet készítetünk, ami felhívja ezekre az épített emlékekre a figyelmet, hasznosítja és új élettel tölt meg egy jelenleg ritkán használt „elfeledett” épületet. Pécs egyik történelmi nevezetessége a török kórból megmaradt épületek összessége, ezek közt akad olyan, ami máig őrzi hagyományos funkcióját, de van, amit átalakítottak és akadnak romok is. Munkánk során végig vettük a város török emlékeit és kiemelve egyet - Idrisz baba türbéjét - egy tervet készítetünk, ami felhívja ezekre az épített emlékekre a figyelmet, hasznosítja és új élettel tölt meg egy jelenleg ritkán használt „elfeledett” épületet.

Kulcsszavak: müemléki épületek, Pécs, török, szakrális, Idrisz baba türbéje, dzsámi. 


\section{Bevezetés}

Pécsen a Török hódoltság korából származó műemlékek a város egyik jelképét képezik, mégis akadnak köztük olyanok, amik jelenleg méltatlan, kihasználatlan helyzetben vannak. Ezen épületek hasznosítását nehezíti az is, hogy más kultúrából származnak és nehéz megérteni eredeti jelentőségüket. Munkánk során megvizsgáltunk több ilyen emléket, azok helyzetét és a hozzájuk kapcsolódó szokásokat. Az így összegyüjtött információk alapján álltunk neki egy látogató központ tervezésének.

\section{Pécs a török korban [1]}

1541-ben a törökök elfoglalták Budát, majd Pécset is megostromolták. Székely Lukács pécsi várkapitány belátta, hogy a város védelmi rendszere elhanyagolt, valamint fekvése nem teszi alkalmassá, hogy megvédjék a várost. Így pedig az ellenállás csak az anyagi javak pazarlásával és a lakosság pusztulásával járt volna, ezért 1543 nyarán kinyitották a város kapuit az oszmán seregek előtt. Ezután a város 143 évre a törökök uralma alá került.

Korbeli leírások alapján 4 küllié (épület-komplexum) 17 imahely, öt vallási főiskola és 11 elemi iskola, hat kolostor, három gőzfürdő, 47 kút, három vendégfogadó, 400 mester által használt piac és bazár, két síremlék és számtalan szórakozóhely képezte a Török kori várost.

\section{Pécs török kori emlékei a mai városban}

\subsection{Dzsámik [1] [2]}

\subsubsection{Jakováli Hasszán pasa dzsámija}

Jakovali Hasszán pasa dzsámija Közép-Európa legegységesebben megmaradt török eredetű imahelye. Pécsett, a Kórháztéren két épülettömb közé beékelődve, szinte elbújik az emberek szeme elől. Mind a mai napig imahelyként funkcionál (e mellet múzeumként is üzemel), így fontos központja a magyarországi muzulmán közösségnek.

\subsubsection{Gázi Kászim pasa dzsámija}

Gázi Kászim pasa dzsámija Magyarország legnagyobb török, vallási épülete. Pécs főterén, a Széchenyi téren álló dzsámi a város egyik jelképe. Ma egy olyan műemlék, ami egy sor rekonstrukció után nyerte vissza eredeti jellemvonásait, de részben új funkcióval, keresztény templomként üzemel tovább.

\subsubsection{Ferhád pasa dzsámija}

Ferhád pasa dzsámija a felsoroltak közül a legrosszabb állapotban lévő épület. A belváros egyik ikonikus épületének, a Polgári Kaszinó elbontásával kerültek elő a török kori maradványok (alap, boltív és ablak részletek). A dervisek számára nagy jelentőséggel bíró dzsámi a török elüzését követően a domonkos rend kezére került és ezután meg is indult a pusztulása. A terület ma magánkézen van, a romok nem látogathatók és gaz növi be őket.

\subsection{Kutak}

Az iszlám kultúrában a kutaknak kettős szerepe van, egyrészt vallási másrészt fontos társadalmi, közéleti szerep is társul a vízhez. Így nem meglepő, hogy minden városban létesültek kutak a hódoltság idején. Ez alól Pécs sem kivétel. Több kút is müködött a város területén. Ezek többsége mára már csak rekonstrukcióként, vagy emlékként látható. Kiemelkedik közülük Idrisz baba kútja mely egy korhű rekonstrukció (az eredeti helyén) és a Káptalan utcai eredeti török kút is.

\subsection{Temetők, türbék [1]}

Pécsen ahány nép megfordult annyi féle szokással és annyiféle helyre temetkeztek. A török időkből származó temetők nehezen behatárolhatók,

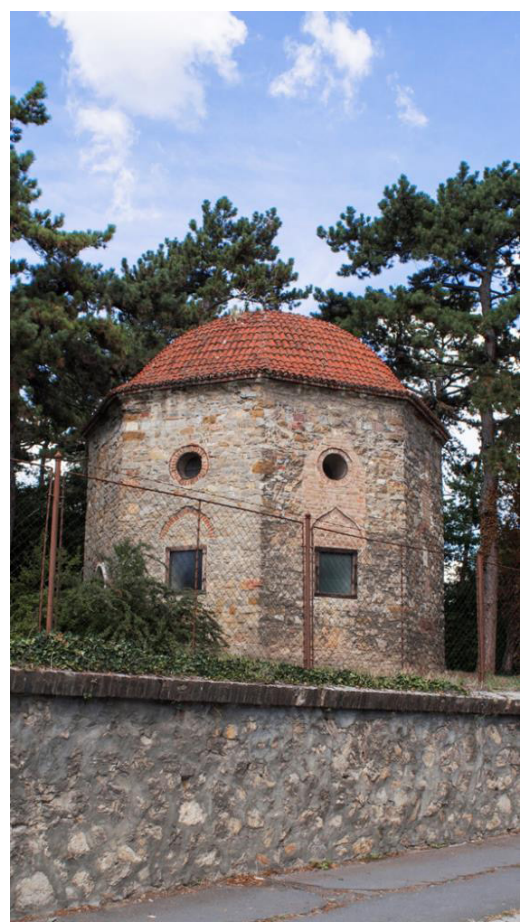

1. ábra. Idrisz baba türbéje 
hiszen sok részre már ráépült a fejlődő város. A régészeti kutatásokból tudjuk, hogy több temető is volt a városban. Ilyenek voltak például Gázi Kászim, Jakolavli Haszán és Ferhád pasa dzsámijai melletti temetők. De török temetkezésre utaló leletek kerültek elő a Szigeti úrtól és az Árkád környékéről is. A legnagyobb temetők minden bizonnyal a mai Rókus utca vonalában és a Szigeti illetve a Budai kapun kívül húzódtak.

\subsubsection{Idrisz baba türbéje [1]}

Pécsen a török temetkezés legnagyobb emléke Idrisz baba türbéje (a türbe egy a sír fölé emelt építmény a Rókus utcai temető része lehetet).

Idrisz baba egy a bektasi dervisrendből származó szent. Türbéjét halála után nem sokkal emelték, mint zarándok helyet, a leírások alapján az 1600-as évek elején. A török elűzését követően az épület sok mindenen ment keresztül. Volt kápolna, korház, lőpor és kötszer raktár is. Míg végül a múlt században újra felfedezték és műemléki védettség alá helyezték. Ekkor kezdődtek meg a felújítások és a kutatások. Az 1960-as években a környéken és az épületben is régészeti ásatásokat végeztek valamint teljes átfogó szerkezeti vizsgálatra is sor került.

Az épület egy nyolcszög alaprajzú kupolával fedett terméskő építmény. A falai vakolatlanok mivel nem találtak megfelelő mintákat a restauráláshoz. Jelenleg időpont egyeztetéssel látogatható.

\section{Idrisz baba türbéje, fejlesztési javaslat}

Előzetesen már elkészült általunk egy közpark terve a pécsi Idrisz baba türbéjéhez, ezzel kívántuk visszaállítani a köztudatba az épületet, valamint a korházhoz közel kialakítani egy átkötő zónát. Már akkor is egy olyan tér megalkotása volt a cél, aminek központi eleme a türbe és tiszteletben tartja az épületet és annak eredetét. Ezt oly módon szándékoztunk elérni, hogy a Korán egy szimbólumát (rub el hizb - a Korán fejezeteinek végét jelölő nyolcágú csillag) felhasználva egy teraszos elrendezést alakítottunk ki, aminek a központja maga a türbe lett. Tanulmányozva az iszlám szokásokat olyan jellemző motívumokat használtunk, mint a víz (az iszlám egyik legfontosabb mozzanatai a rituális mosdások), a növényzet (füszernövények, esetlegesen a törökökre hagyományosan jellemző virágok) és a szín világ (az iszlám és török temetők legfőbb színe a fehér). Ezt tovább fejlesztve dr. Kósa Balázzsal egy olyan épület és tér vázlat tervét készítettük el, ami folytatja, a fent említett nézeteket és kihasználja a türbe elhelyezkedését, valamint új funkciót kölcsönöz a helynek. Megvizsgáltuk továbbá a helyi török értékeket és ezekből felhasználtunk több jellegzetességet is, valamint figyelembe vettük a meglévő emlékek mai helyzetét. A közpark tervét kibővítve és fejlesztve a rekreációs zóna mellett megjelent az ismeretterjesztés és a tájékoztatás.

Fontosnak tartottuk, hogy ne az új épület legyen a fókuszban, hanem a műemlék. Így a meglévő munka alapjain kezdet alakot ölteni egy olyan köztér terve ahol a fő közlekedő sávok mind a türbe felé tartanak, ezzel is kiemelve azt. Megjelentek a pihenő területek közelében virágágyások és pontszerú vízfelületek is.

Hamar felvetődött az ötlet, miszerint a területet továbbra is teraszos módon akarjuk átalakítani mi lenne, ha az épületet a türbe köré a földbe helyeznénk el. Végül e mellett a megoldás mellett határoztuk el magunkat, így a türbe körül kialakított tér alatt létre hoztunk egy kiállító teret, amiben meg jelenik a türbe alakja.

A bejáratot egy az utca szintről levezető nyaktaggal (a lejutást egy rámpa és egy lépcsősor is biztosítja) képzeltük le, ami folyamatosan lejtve belesimul, a már említett térbe. Úgy terveztük, hogy a földfelszínen csak ez a nyaktag jelenik meg és jelzi új épületünket. Burkolatára két féle gondolat merült fel, az első a fehér látszóbeton falak, a második pedig világos színű csiszolt kőlapok mind fedésként, mind az oldalakon. A tervezett bejárati ajtót egy perforált corten acél ajtó, amibe tervünk

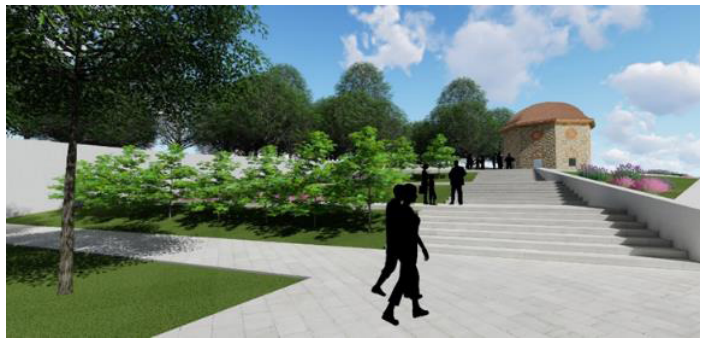

2. ábra. Tervezett park bejárat

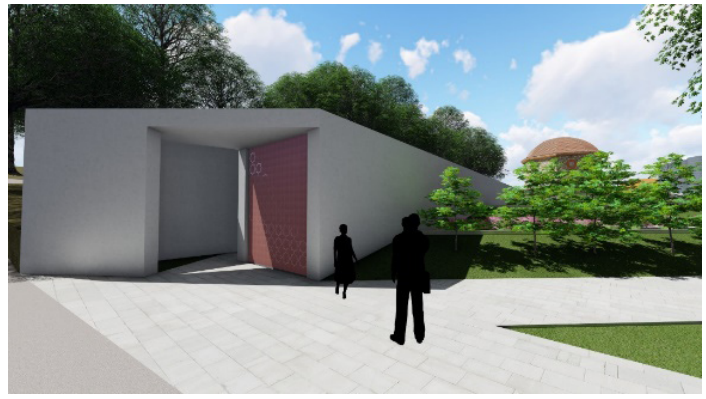

3. ábra. Tervezett látogatóközpont bejárat 


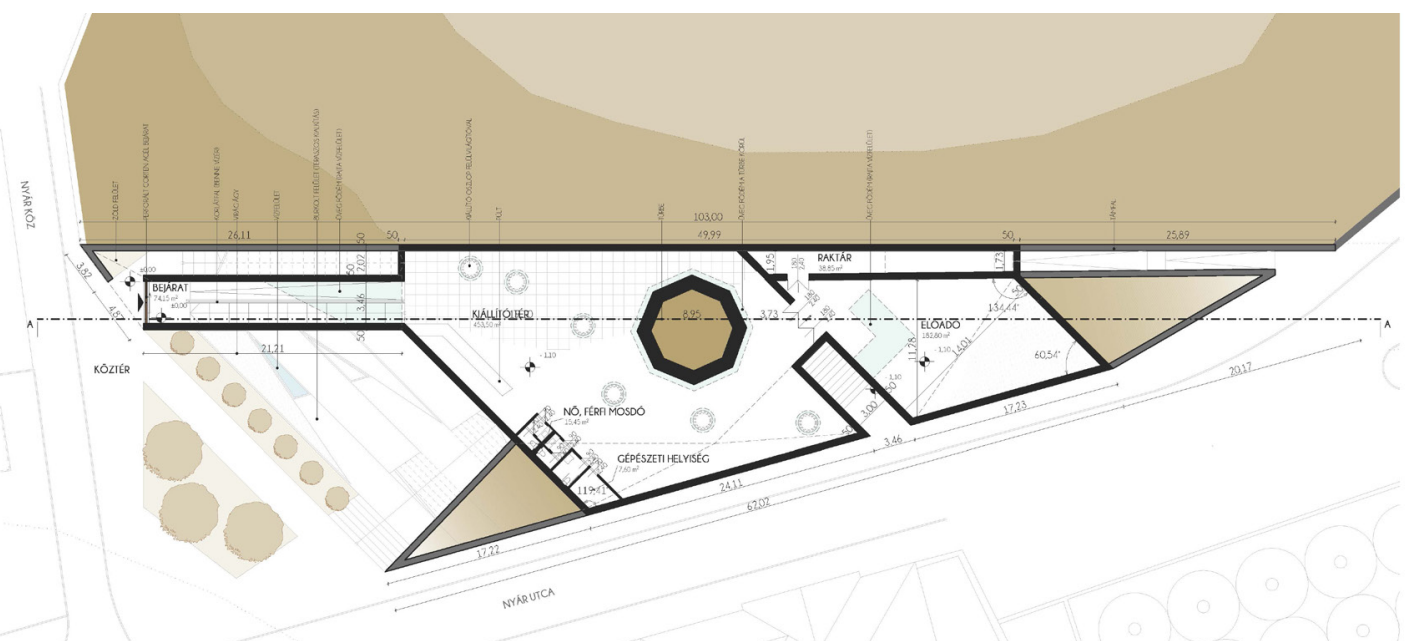

4. ábra. Tervezett látogatóközpont alaprajza

szerint LED panel kerül így egy szabályos perforálással, mint egyszerü kivetítőt lehetne használni (megjeleníthetők lennének különböző török szimbólumok, amelyek a türbe eredetére utalnak). A bejárat természetes megvilágítását a térhez közeledve egy üvegfödém részlet adja, amelynek tetején víz jelenik meg. A vizet szándékaink szerint belül is szeretnénk megjeleníteni oly módon, hogy a lépcsősort és a rámpát elválasztó fal tetején apró erecske fut le a kiállítótérbe.

A tervezet kiállítóban rögtön az érkezéssel szemben megjelenik a türbe alakja, mint egy érdekes sziluettet képző műtárgyként. Továbbá pontszerűen elhelyezett, gyűrü alakú felülvilágítók és emelvények kombinációjával egy modern kiállítótérbe érkezik a látogató. Ebbe a térbe került a fogadó zóna is (pult képében, ami el látja a pénztár és a „múzeumshop” feladatáét is) valamint a szociális helyiségek is innen nyílnak.

Azért, hogy minden korosztály számára érdekessé tegyük, és hogy plusz oktatási funkcióval lássuk el az épületet a keleti részen kialakításra került egy előadó tér, amit kifejezetten virtuális a valóság eszközeivel szerelnénk fel. A hagyományos muzeológiai bemutatás helyett - ami valószínűleg nem lenne elég csábító - a modern technikával egy olyan attrakció keletkezne, ami nem csak a turizmus számára lenne hasznos, hanem a helyi oktatást is segítené.

\section{Köszönetnyilvánítás}

Az Emberi Erőforrások Minisztériuma ÚNKP-18-1-IPTE-186 kódszámú Új Nemzeti Kiválóság Prog-ramjának támogatásával készült.

\section{Szakirodalmi hivatkozások}

[1] Varga S.: Irem kertje. Pécs története a hódoltság korában 1526-1686. 1526-1686 Pécsi Püspöki Hittudományi Főiskola, Pécs, 2009. 59-64.; 109-124; 163-170.

[2] Sudár B.: A pécsi Idrisz baba-türbe. Forster Gyula Nemzeti örökséggazdálkodási és szolgáltatási Központ, Budapest, 2013. 9-70.

[3] Hancz E., Varga Sz.: Pécs mindennapjai a török félhold alatt. Pannon Kultúra Alapítvány - Janus Pannonius Múzeum; Pécs, 2013. 39-65. 